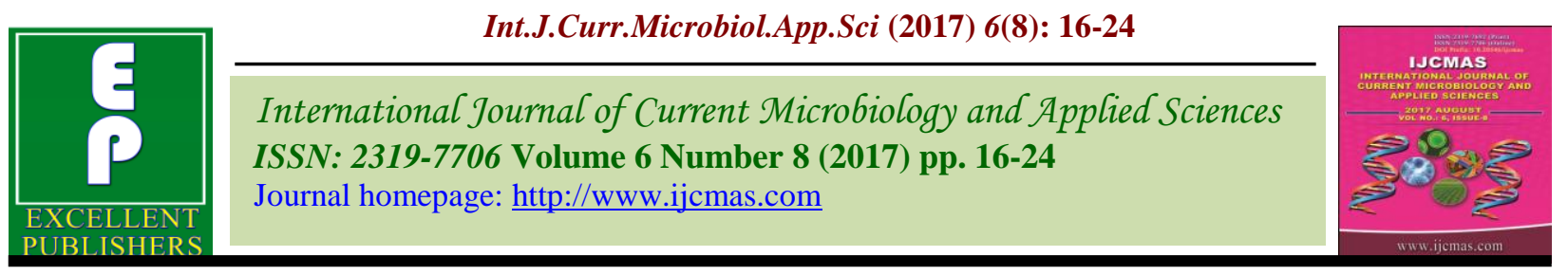

Original Research Article

https://doi.org/10.20546/ijcmas.2017.608.004

\title{
Development of Portable Modified Atmospheric Packaging (MAP) Unit for Disinfestation of Food Grains
}

\author{
Ambrish Ganachari*, P.F. Mathad, Udaykumar Nidoni and Nagaraj Naik \\ Department of Processing and Food Engineering, College of Agricultural Engineering, \\ University of Agricultural Sciences, Raichur - 584 104, Karnataka, India \\ *Corresponding author
}

\section{A B S T R A C T}

Keywords

Modified atmospheric packaging unit, Disinfestations, MAP of Bengal gram.

Article Info

Accepted:

04 June 2017 Available Online:

10 August 2017
A portable modified atmospheric packaging (MAP) unit was developed for grain disinfestation. The developed MAP unit consisted of a grain holding unit and cover, sealing unit, flushing nozzle, pressure regulator, solenoid valve with timer, working table and carbon dioxide cylinder. The operational parameters of the developed MAP unit viz., flushing pressure and flushing duration was optimized for Bengal gram. The flushing pressure of $5 \mathrm{~kg} / \mathrm{cm}^{2}$ for $10 \mathrm{~s}$ was found to retain maximum concentration of $\mathrm{CO}_{2}(94.8 \%)$ and minimum of $\mathrm{O}_{2}(0.1 \%)$ in Bengal gram packages of one kg capacity with highest desirability of $97.8 \%$. The results on storage of Bengal gram showed no incidence of infestation and highest germination (\%) in PET packages compared to PE and PP at the end of nine months. Similarly, $\mathrm{CO}_{2}$ retention was observed to be for longer period in PET compared to PE and PP. The estimated cost of the developed MAP unit was found to be Rs. 8350.00 and the cost of packaging was worked out to be Rs. 2.90 for PET followed by PE and PP each of Rs.1.90.

\section{Introduction}

Agriculture is an important sector of Indian economy contributing about $17 \%$ to the GDP and provides employment to over $60 \%$ of the population (Kekane, 2013). Indian agriculture has registered impressive growth over last few decades and helped India to mark its global presence. Grain production has been steadily increasing due to advanced production technologies, but improper storage resulted in high losses. During storage, quantitative as well as qualitative losses occur due to insects, rodents and micro-organisms. Grain storage plays an important role in preventing losses which are caused mainly due to weevils, beetles, moths and rodents (Kartikeyan et al., 2009). It is estimated that $60-70 \%$ of food grain produced in the country is stored at home level in indigenous storage structures, however they are not suitable for storing grains for very long periods (Mishra et. al., 2012). Here in lies the significance of improved and scientific storage of grains. Many studies have shown that modified atmosphere (MA) of elevated $\mathrm{CO}_{2}$ and depleted $\mathrm{O}_{2}$ is lethal to pests and microorganisms during the storage. Modified atmospheric storage is a well-proven technology for preserving natural quality of 
food products in addition to extending the storage life (Jayas and Jeyamkondan, 2002). At the same time consumers today expect the food products to be chemical and pesticide free or with lower levels of residues. Hence, it is demanding to develop alternative methods that are economically feasible and ecologically adjusted to control storage grain insects and fungi (Moreno-Martinez et al., 2000). Even though modified atmosphere packaging is the effective method for storing the grains without spoilage and it may help to improve the shelf life of the grains effectively still it has some limitations like higher initial cost. Hence an attempt is made to develop a small scale portable modified atmospheric packaging unit.

\section{Materials and Methods}

\section{Selection of food grains}

Survey was conducted to know the major food grains grown in the region, their production and shelf life. Based on the study Bengal gram, rice and sorghum were selected for design of the modified atmospheric unit.

\section{Physical properties of selected food grains}

The physical properties of grains relevant to the design of portable modified atmospheric packaging unit viz., bulk density, true density and porosity were determined. The bulk density was determined as the ratio of mass of the sample and volume occupied by it (Mangaraj and Singh, 2005). The true density was determined by toluene displacement method as given by Mohsenin, (1986). Porosity was computed from the value of particle density and bulk density using the equation given by Mohsenin, (1986).

\section{Selection of packaging material}

The commonly available packaging materials viz., polyethylene (PE), polypropylene (PP) and polyethylene terephthalate (PET) having $100 \mu$ thickness were used. The dimension was selected based on bulk density and head space required for filling gas. Five $\mathrm{kg}$ capacity packaging material was used for designing the MAP unit and one kg capacity for studying the quality parameters of packaged food grains.

\section{Development of portable modified atmospheric unit}

A portable modified atmospheric packaging (MAP) unit was designed, developed and tested for disinfestations of Bengal gram. The developed unit consists of a grain holding unit, top cover, sealing unit, nozzle, pressure regulator, solenoid valve with timer, working table and carbon dioxide cylinder.

\section{Grain holding unit}

The dimensions of grain holding unit are designed based upon the quantity of grains to be packed, dimension of sealing unit and space to accommodate other accessories. Based on the water capacity of the packaging material and volume of the grains the dimension of the packaging material was selected. The unit was designed for packing of $5 \mathrm{~kg}$ grain capacity.

Standard packaging material size for $5 \mathrm{~kg}$ capacity $-450 \times 300 \mathrm{~mm}$

Length of the grain holding unit $(\mathrm{L})=$ Length of packaging material + Width of the sealing unit + Length of the nozzle $=450+100+50$ $=600 \mathrm{~mm}$

Width of the grain holding unit $(\mathrm{W})=$ Length of the sealing unit space + Free board $=400+$ $50=450 \mathrm{~mm}$

Height of the grain holding unit $(\mathrm{H})=$ Height of the packaging machine + Free board $=140$ $\mathrm{mm}+60 \mathrm{~mm}=200 \mathrm{~mm}$ 
The final dimensions $=\mathrm{L} \times \mathrm{W} \times \mathrm{H}=600 \times$ $450 \times 200 \mathrm{~mm}$

Plywood of $8 \mathrm{~mm}$ thick was used as construction material considering its durability and cost.

\section{Top cover of grain holding unit}

Transparent fiber sheet of $5 \mathrm{~mm}$ thick was used as top cover so as to make sure the operation of gas flushing and sealing are visible to avoid the possible errors.

Accordingly, the dimensions of cover were selected as $615 \mathrm{~mm}$ and $465 \mathrm{~mm}$ based on grain holding unit.

\section{Sealing unit}

The sealing machine was selected based on dimensions of packaging material and the standard sizes of sealing machine available in the market. The sealing unit of SEPACK brand (model-300 DELTAS) with seal dimensions of $300 \times 1.6 \mathrm{~mm}$ was used.

\section{Nozzle}

The nozzle was used for flushing the gas and dimensions were selected based on the standard sizes available in market. Nozzle of $50 \mathrm{~mm}$ length with $2 \mathrm{~mm}$ of orifice was selected.

\section{Pressure regulator}

It was provided for regulating the pressure and flow volume. The commercially available gas regulator with maximum pressure range of $16 \mathrm{~kg} / \mathrm{cm}^{2}$ with orifice of $6 \mathrm{~mm}$ was used.

\section{Solenoid value with timer}

Timer controlled solenoid valve was used to control the flow of gas. Commercially available solenoid valve of 2/2-way midget direct acting normally closed and energized to open type with $6 \mathrm{~mm}$ orifice was used with digital timer ranging 0.5-45 minutes.

\section{Working table}

The MAP unit was placed on a portable working table made of cast iron angles. Dimensions of table are designed based on the dimensions of the MAP unit and operators ergonomics. The dimensions designed are 620 $\times 470 \times 850 \mathrm{~mm}$ for $\mathrm{L} \times \mathrm{W} \times \mathrm{H}$.

\section{Carbon dioxide cylinder}

The commercially available carbon dioxide cylinder having $30 \mathrm{~kg}$ capacity with a total volume of gas equal to $47.4 \mathrm{~m}^{3}$ was used for the experiment.

\section{Performance evaluation of developed MAP unit}

The performance of developed MAP unit was evaluated after optimizing the operational parameters of MAP unit in terms of quality of packaged grains/seeds during storage period.

The optimization of operating parameters viz., flushing pressure and flushing duration for the developed MAP unit was carried to achieve target composition of gases in the grain packages using statistical software Design Expert with two responses $\left(\mathrm{CO}_{2}\right.$ maximization $>60 \%$ and $\mathrm{O}_{2}$ minimization $<3 \%)$ in the range.

The target gas concentrations considered for insect toxicity were $3 \%$ or less of $\mathrm{O}_{2}$ and $60 \%$ or more of $\mathrm{CO}_{2}$ (Mbata et al., 2004).

The flushing of gas was carried out at four different pressures viz., 2, 3, 4 and $5 \mathrm{~kg} / \mathrm{cm}^{2}$ and flushing durations viz., 5, 10, 15 and $20 \mathrm{~s}$ for Bengal gram based on trial experiments. 


\section{Gas composition in the package}

The gas concentration in package was measured using gas analyzer (Model-Check point; Make-PBI Dansensor, Denmark) at monthly interval during storage period.

\section{Quality parameters of packaged grains/seeds}

The quality parameters viz., per cent insect damage and germination percentage for packaged grains/seeds were estimated for nine months at monthly interval during storage.

Pulses suffer a great damage during storage due to insect attack and Bengal gram is one of the important pulse crop of the HK region.

Hence, Bengal gram was selected for storage study and is severely attacked by bean beetle resulting losses in quantity and nutritional quality (Muhammad Sarwar, 2012).

\section{Per cent insect damage}

Insect damage was assessed by counting method as described by Wambugu et al., (2009). It was estimated by drawing 100 seeds from each replication at random and damaged seeds attributed to insects (with holes, eggs or both) were recorded by observation and expressed in percentage on number basis.

\section{Germination percentage}

Germination test was conducted with three replicates of 100 seeds each in the paper medium and kept in the walk-in germinator maintained at $25 \pm 1^{\circ} \mathrm{C}$ temperature and $90 \pm 2 \% \mathrm{RH}$. At the end of sixth day, the number of normal seedlings in each replication was counted and the germination was calculated and expressed in percentage (ISTA, 2013).

\section{Economics of developed unit}

The economic analysis is an important part of any technology, since it determines the cost benefit ratio and adoptability of the technology. The cost of the developed MAP unit and the cost of packaging were computed.

\section{Results and Discussion}

\section{Physical properties of selected food grains}

Grain properties relevant to the design of MAP unit were determined for rice, Bengal gram and sorghum and results are presented in table 1 .

From the table, it is observed that mean values of bulk density for Bengal gram, rice and sorghum were recorded as 818,838 and $821 \mathrm{~kg} / \mathrm{m}^{3}$, respectively with highest value for rice followed by sorghum and Bengal gram.

The average values of particle density were determined to be $1330,1428,1304 \mathrm{~kg} / \mathrm{m}^{3}$ for Bengal gram, rice and sorghum, respectively. The calculated porosity was $38.47,41.29$ and $37.03 \%$ for Bengal gram, rice and sorghum, respectively.

Similar results were reported by Kanchana $e t$ al., (2012), Jambamma et al., (2011) and Nikoobin et al., (2009).

\section{Selection of packaging material}

Based on bulk density of grains and water capacity of packages, the commercially available packaging materials of one $\mathrm{kg}$ capacity with $203 \times 305 \mathrm{~mm}, 100 \mu$ were selected for the performance study.

The dimensions of packaging materials are presented in table 2 . 
Design of modified atmospheric packaging unit

The specifications of the developed portable MAP unit are presented in table 3 and the schematic diagram in figure 1 .

\section{Performance evaluation of developed MAP unit}

The recorded and analyzed data for performance evaluation of MAP are presented below.

The data on average of replications for gas composition in Bengal gram packages immediately after flushing are presented in table 4. It is observed that, flushing pressure and duration had significant effect on concentration of flushed gas. The solutions provided by optimization tool showed the flushing of $\mathrm{CO}_{2}$ at $5 \mathrm{~kg} / \mathrm{cm}^{2}$ for $10 \mathrm{~s}$ had 97.8\% desirability for Bengal gram.

\section{Retention of carbon dioxide and oxygen in grain packages}

The variations of $\mathrm{CO}_{2}$ and $\mathrm{O}_{2}$ concentration for Bengal gram packets during storage are presented in table 5. It is observed that $\mathrm{CO}_{2}$ composition reduced and attained atmospheric condition within one month of storage in PE and PP packets, whereas PET retained higher levels of $\mathrm{CO}_{2}$ upto three months. Similarly, oxygen composition turned to atmospheric condition within one month for all packaging materials.

This might be due to higher permeability $\mathrm{PE}$ and $\mathrm{PP}$ for $\mathrm{CO}_{2}$ and $\mathrm{O}_{2}$ gases compared to PET. Similar reports have been published by Valentina (2012).

Fig.1 Schematic diagram of modified atmospheric packaging (map) unit

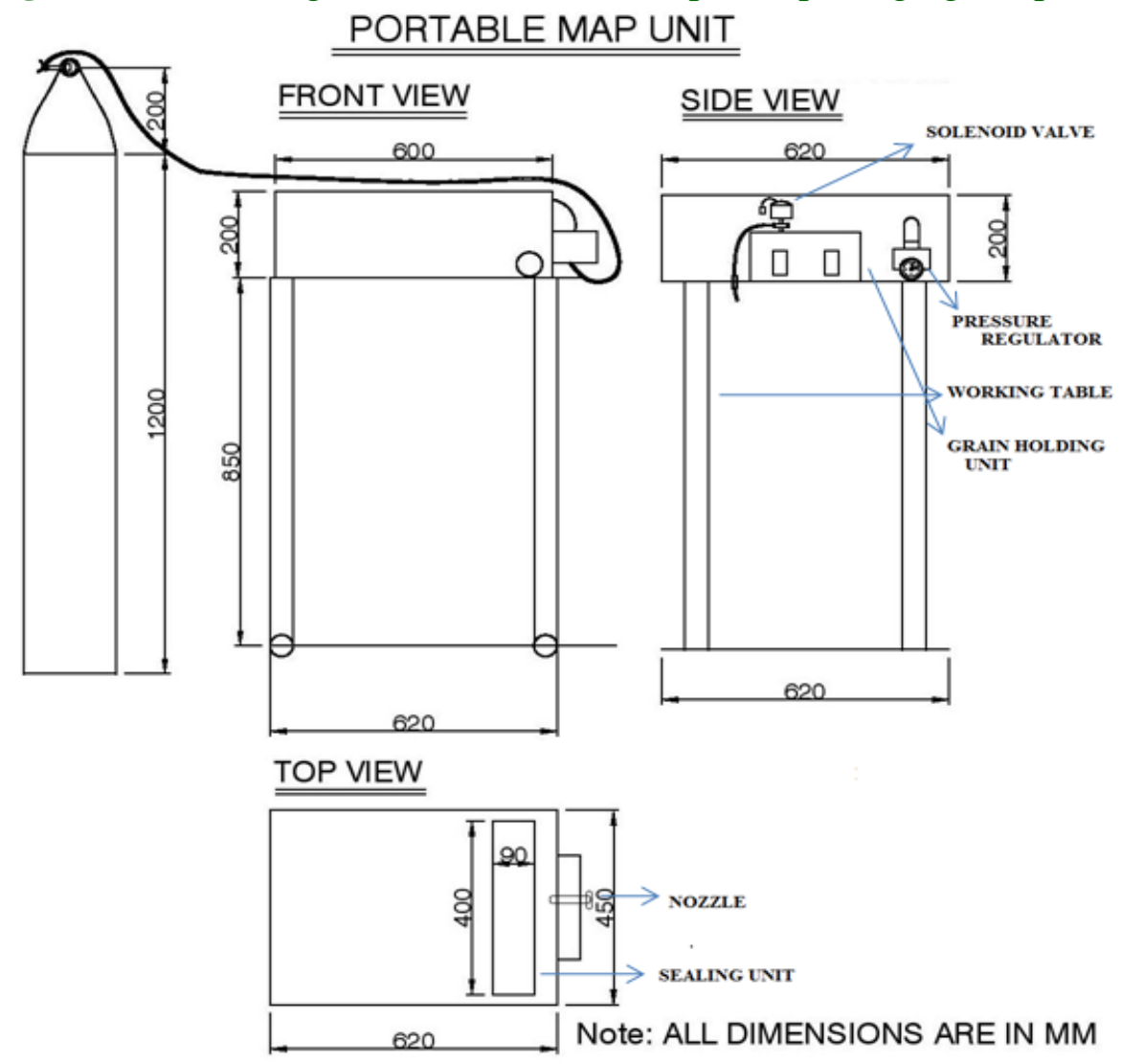


Table.1 Physical properties of the selected grains

\begin{tabular}{|l|l|c|c|c|}
\hline \multirow{2}{*}{$\begin{array}{c}\text { SI. } \\
\text { No }\end{array}$} & \multirow{2}{*}{ Parameters } & \multicolumn{3}{|c|}{ Commodity } \\
\cline { 3 - 5 } & & Bengal gram & Rice & Sorghum \\
\hline 1. & Bulk density, $\left(\mathrm{kg} / \mathrm{m}^{3}\right)$ & 818 & 838 & 821 \\
\hline 2. & Particle density, $\left(\mathrm{kg} / \mathrm{m}^{3}\right)$ & 1330 & 1428 & 1304 \\
\hline 3. & Porosity, $(\%)$ & 38.47 & 41.29 & 37.03 \\
\hline
\end{tabular}

Table.2 Dimensions of one kg capacity packaging materials

\begin{tabular}{|l|c|c|c|}
\hline Packaging materials & Size $\left(\mathbf{m m}^{\mathbf{2}}\right)$ & Thickness $(\boldsymbol{\mu})$ & Water capacity $\left.\mathbf{( c m}^{\mathbf{3}}\right)$ \\
\hline Poly ethylene (PE) & $203 \times 305$ & 105 & 1890 \\
\hline Polypropylene (PP) & $203 \times 305$ & 101 & 1740 \\
\hline Polyethylene terephthalate (PET) & $203 \times 305$ & 103 & 1770 \\
\hline
\end{tabular}

Table.3 Design specifications of portable modified atmospheric packaging unit

\begin{tabular}{|l|l|}
\hline \multicolumn{1}{|c|}{ Parts of MAP } & \multicolumn{1}{c|}{ Specifications } \\
\hline Grain holding unit & $\mathrm{L} \times \mathrm{W} \times \mathrm{H}-600 \times 450 \times 200 \mathrm{~mm}$ \\
\hline Top cover & $\mathrm{L} \times \mathrm{W} \times \mathrm{T}-615 \times 465 \times 5 \mathrm{~mm}$ \\
\hline Sealing unit & $\begin{array}{l}\mathrm{L} \times \mathrm{W} \times \mathrm{H}-400 \times 90 \times 140 \mathrm{~mm} \\
\text { Seal dimensions }-\mathrm{L} \times \mathrm{T}-300 \times 1.6 \mathrm{~mm}\end{array}$ \\
\hline Nozzle & $\mathrm{L} \times \mathrm{D}-50 \times 8 \mathrm{~mm}$, Orifice $-2 \mathrm{~mm}$ \\
\hline Solenoid valve & $\begin{array}{l}2 / 2-\text { Way Midget Type, Normally Closed } \\
\text { Size }-6 \mathrm{~mm}(1 / 4 "), \text { Orifice }-3.0 \mathrm{~mm} \text {, Max. Pressure }-12 \mathrm{bar}\end{array}$ \\
\hline Pressure regulator & Model - OR Mini $(1 / 4 ')$, Pressure $($ Max $) \mathrm{P} 1-16 \mathrm{~kg} / \mathrm{cm}^{2}$ \\
\hline Working table & $\mathrm{L} \times \mathrm{W} \times \mathrm{H}-620 \times 470 \times 850 \mathrm{~mm}$ \\
\hline
\end{tabular}

Table.4 Average data on composition of gas in Bengal gram packages

\begin{tabular}{|c|c|c|c|c|c|c|c|c|c|c|c|c|c|c|c|c|}
\hline Pressure, & \multicolumn{4}{|c|}{$2 \mathrm{~kg} / \mathrm{cm}^{2}$} & \multicolumn{4}{|c|}{$3 \mathrm{~kg} / \mathrm{cm}^{2}$} & \multicolumn{4}{|c|}{$4 \mathrm{~kg} / \mathrm{cm}^{2}$} & \multicolumn{4}{|c|}{$5 \mathrm{~kg} / \mathrm{cm}^{2}$} \\
\hline Time, $s$ & 5 & 10 & 15 & 20 & 5 & 10 & 15 & 20 & 5 & 10 & 15 & 20 & 5 & 10 & 15 & 20 \\
\hline $\mathrm{CO}_{2}, \%$ & 91.6 & 92.6 & 92.3 & 94.8 & 85.0 & 92.7 & 91.6 & 92.5 & 91.9 & 94.5 & 91.0 & 94.6 & 90.5 & 94.8 & 93.1 & 93.8 \\
\hline $\mathrm{O}_{2}, \%$ & 0.5 & 0.6 & 0.7 & 0.1 & 2.1 & 0.6 & 0.7 & 0.6 & 0.6 & 0.1 & 0.9 & 0.1 & 1.0 & 0.1 & 0.4 & 0.3 \\
\hline
\end{tabular}


Table.5 Retention of $\mathrm{CO}_{2}$ and $\mathrm{O}_{2}$ gas for Bengal gram in different Packaging materials during storage

\begin{tabular}{|c|c|c|c|c|c|c|c|c|c|c|}
\hline \multirow{2}{*}{$\begin{array}{l}\text { Packaging } \\
\text { Materials }\end{array}$} & \multicolumn{10}{|c|}{ Storage period, months } \\
\hline & $\mathbf{0}$ & 1 & 2 & 3 & 4 & 5 & 6 & 7 & 8 & 9 \\
\hline \multicolumn{11}{|c|}{ Carbon dioxide, \% } \\
\hline $\mathrm{PE}$ & 94.4 & 0 & 0 & 0 & 0 & 0 & 0 & 0 & 0 & 0 \\
\hline $\mathrm{PP}$ & 94.25 & 0 & 0 & 0 & 0 & 0 & 0 & 0 & 0 & 0 \\
\hline PET & 93.95 & 21.6 & 12.6 & 0 & 0 & 0 & 0 & 0 & 0 & 0 \\
\hline \multicolumn{11}{|c|}{ Oxygen, \% } \\
\hline $\mathrm{PE}$ & 0.14 & 20.9 & 20.9 & 20.9 & 20.9 & 20.9 & 20.9 & 20.9 & 20.9 & 20.9 \\
\hline $\mathrm{PP}$ & 0.05 & 20.9 & 20.9 & 20.9 & 20.9 & 20.9 & 20.9 & 20.9 & 20.9 & 20.9 \\
\hline PET & 0.14 & 20.9 & 20.9 & 20.9 & 20.9 & 20.9 & 20.9 & 20.9 & 20.9 & 20.9 \\
\hline
\end{tabular}

Table.6 Per cent insect damage for Bengal gram in different packaging materials during storage

\begin{tabular}{|l|c|c|c|c|c|c|c|c|c|}
\hline \multirow{2}{*}{ Packaging materials } & \multicolumn{10}{|c|}{ Storage period, months } \\
\cline { 2 - 12 } & $\mathbf{1}$ & $\mathbf{2}$ & $\mathbf{3}$ & $\mathbf{4}$ & $\mathbf{5}$ & $\mathbf{6}$ & $\mathbf{7}$ & $\mathbf{8}$ & $\mathbf{9}$ \\
\hline Poly ethylene (PE) & 0 & 0 & 0 & 0 & 0 & 1.0 & 2.5 & 3.5 & 5.0 \\
\hline Polypropylene (PP) & 0 & 0 & 0 & 0 & 0 & 0.5 & 1.5 & 3.0 & 4.0 \\
\hline Polyethylene terephthalate (PET) & 0 & 0 & 0 & 0 & 0 & 0.0 & 0.0 & 0.0 & 0.0 \\
\hline
\end{tabular}

Table.7 Germination percentage for Bengal gram in different packaging materials during storage

\begin{tabular}{|c|c|c|c|c|c|c|c|c|c|c|}
\hline \multirow{2}{*}{$\begin{array}{l}\text { Packaging } \\
\text { materials }\end{array}$} & \multicolumn{10}{|c|}{ Storage period, months } \\
\hline & $\mathbf{0}$ & 1 & 2 & 3 & 4 & 5 & 6 & 7 & 8 & 9 \\
\hline Poly ethylene (PE) & 100.0 & 100.0 & 99.3 & 99.0 & 99.0 & 97.0 & 96.5 & 96.0 & 95.5 & 94.0 \\
\hline Polypropylene (PP) & 100.0 & 100.0 & 99.3 & 99.6 & 98.0 & 97.5 & 97.5 & 96.5 & 95.0 & 94.5 \\
\hline $\begin{array}{l}\text { Polyethylene } \\
\text { terephthalate(PET) }\end{array}$ & 100.0 & 100.0 & 99.6 & 99.6 & 99.0 & 99.0 & 98.5 & 98.0 & 97.5 & 97.5 \\
\hline
\end{tabular}

\section{Quality parameters}

The quality parameters of grains packaged in selected packaging materials were determined at an interval of one month during storage.

\section{Per cent insect damage}

The data on per cent insect damage influenced by MAP conditions during storage is presented in table 6 . It was observed that, no incidence of infestation was found upto five months but, from sixth month onwards infestation was observed in $\mathrm{PE}$ and $\mathrm{PP}$ packages. Whereas, PET packages were free from infestation even after nine months. The results are in agreement with Ramesh babu et al., (1991) and Mbata et al., (2004).

\section{Germination percentage}

The results of germination as influenced by MAP conditions during storage are presented in table 7. It is observed that, germination percentage declined with advancement of storage period. Germination percentage was 
highest for Bengal gram stored in PET packets which is $100 \%$ at initial stage and decreased to $97.5 \%$ at the end of nine month. In PE and PP packages it declined from $100 \%$ to $94.0 \%$ and $94.5 \%$, respectively. The probable reason for differences in longevity might be due to reduced respiration and aging of the seeds by higher concentration of $\mathrm{CO}_{2}$. Similar results have also been reported by and Bera et al., (2008).

\section{Economics of developed unit}

The cost of developed MAP unit was estimated to be Rs. 8,350.00 and cost of operation was found to be Rs. 0.90 per packet. The cost of modified atmospheric packaging of Bengal gram was Rs.2.90 for PET followed by PE and PP each of Rs.1.90, respectively.

In conclusion, the developed portable MAP unit consisted of a grain holding unit, sealing unit, flushing nozzle, pressure regulator, solenoid valve with timer, working table and $\mathrm{CO}_{2}$ cylinder. The flushing pressure of 5 $\mathrm{kg} / \mathrm{cm}^{2}$ for $10 \mathrm{~s}$ duration was found to flush maximum concentration of $\mathrm{CO}_{2}(94.8 \%)$ and minimum of $\mathrm{O}_{2}(0.1 \%)$ in the Bengal gram packages of one $\mathrm{kg}$ capacity having highest desirability of $97.8 \%$. The performance evaluation showed no incidence of infestation in PET packages compared to $\mathrm{PE}$ and $\mathrm{PP}$ packages and germination was also observed to be highest for Bengal gram packed in PET $(97.5 \%)$ compared to $\mathrm{PE}(94.0 \%)$ and $\mathrm{PP}$ $(94.5 \%)$ packages at the end of nine months of storage. The estimated cost of the MAP unit was found to be Rs. 8350.00 and the cost of packaging was worked out to be Rs. 2.90 for PET followed by PE and PP each of Rs.1.90.

\section{References}

Bera, Sinha S.N., Ashoka Gaur and Shrivastav, C. 2008. Effect of modified atmospheric storage on seed quality parameters of paddy. Seed Res. 36(1):56-63

Jambamma, Imaya Kumari, A., and Kailappan, R. 2011. Study of physicochemical properties of food grain sorghum and product ready to cook mix food from sorghum. Int. J. Recent Scientific Research 1(3):96-99

Jayas, D.S., and Jeyamkondan, S. 2002. Modified atmosphere storage of grains meats fruits and vegetables. Biosystems Eng. 82:235-251

Kanchana, S, Lakshmi Bharathi, S, Ilamaran, M., and K. Singaravadivel. 2012. Physical quality of selected rice varieties. World Journal of Agricultural Sciences 8(5):468-472

Kartikeyan, C., Veeraraghavantham, D., Karpagam, D., and Firdouse, S.A. 2009. Traditional storage practices. Indian Journal of Traditional Knowledge 8(4):564-568

Kekane, M.A. 2013. Indian agriculture Status, importance and role in Indian economy. International Journal of Agriculture and Food Science Technology 4(4):343-346

Mangaraj, S., and Singh, R. 2005. Studies on some engineering properties of Jatropha for use as biodiesel. Bioenergy News 9:18-20

Mbata, G. N., Phillips, T.W., and Payton, M. 2004. Mortality of eggs of storedproduct insects held under vacuum: effects of pressure, temperature, and exposure time. Journal of Economic Entomology 97(2):695-702

Mishra, P., Prabuthas and Mishra, H.N. 2012. Quality assurance and safety of crops \& foods. First ICC India Grains Conference, in partnership with ICRISAT Special Issue 4(3): 144

Mohsenin, N.N. 1986. Physical Properties of Plant and Animal Materials. Taylor and Francis, New York. 
Moreno-Martinez, E., Jiménez, S., and Vazquez, M.E. 2000. Effect of Sitophilus zeamais and Aspergillus chevalieri on the oxygen level in maize stored hermetically. J. Stored Products Res. 36:25-36

Muhammad Sarwar. 2012. Assessment of resistance to the attack of bean beetle Callosobruchus maculatus (Fabricius) in chickpea genotypes on the basis of various parameters during storage. Songklanakarin J. Sci. Technol. 34 (3):287-291

Nikoobin, M., Mirdavardoost, F., Kashaninejad, F., and Soltani, A. 2009. Moisture-dependent physical properties of chickpea Seeds. Journal of Food Process Engineering 32:544-564
Rameshbabu, M., Jayas, D. S., and White, N. D. G. 1991. Mortality of Cryptolestes ferrugineus (Stephens) adults and eggs in elevated carbon dioxide and depleted oxygen atmospheres. Journal of Stored Product Research 27(3):163-170

Valentina Siracusa. 2012. Food packaging permeability behaviour: A report. International Journal of Polymer Science. Vol (2012). http://dx.doi.org/10.1155/2012/302029

Wambugu, P.W., Mathenge, P.W., Auma, E.O., and Rheenen, H.A. 2009. Efficacy of traditional maize (Zea mays L.) seed storage methods in Western Kenya. African Journal of Food Agriculture, Nutrition and Development 9:11101128

\section{How to cite this article:}

Ambrish Ganachari, P.F. Mathad, Udaykumar Nidoni and Nagaraj Naik. 2017. Development of Portable Modified Atmospheric Packaging (Map) Unit for Disinfestation of Food Grains. Int.J.Curr.Microbiol.App.Sci. 6(8): 16-24. doi: https://doi.org/10.20546/ijcmas.2017.608.004 